\title{
Reaction of Some Chickpea Germplasm Lines against Root Knot Nematode, Meloidogyne incognita (Kofoid and White) Chitwood
}

\author{
Rayanta Kumar Lala ${ }^{1}$, S. Mondal (Ghosh) ${ }^{2^{*}}$ and G. Chakraborty ${ }^{1}$ \\ ${ }^{1}$ Department of Agricultural Entomology, Bidhan Chandra Krishi Viswavidyalaya, Mohanpur, \\ Nadia- 741252, West Bengal, India \\ ${ }^{2}$ AICRP on Nematodes in Agriculture, Directorate of Research, Bidhan Chandra Krishi \\ Viswavidyalaya, Kalyani, Nadia- 741235, West Bengal, India \\ *Corresponding author
}

\section{A B S T R A C T}

Ke y w o r d s
Root knot
nematode,
Chickpea,
Germplasm,
Meloidogyne
incognita, Resistant,
Susceptible, Root
gall index

Keywords

Root knot

Germplasm

Meloidogyne

incognita, Resistant

Susceptible, Root

\section{Introduction}

Pulse crops possess an important position in India as they contain nearly three times as much protein as in the cereals. Basically, these are the main source of dietary protein (Jeswani and Vanchaik, 1986; Chand and Srivastava, 1982) for a large vegetarian population in our country. On an average, pulses contain 22 to 24 per cent protein as against 8 to10 per cent in cereals. Chickpea (Cicer arietinum $\mathrm{L}$ ), a pulse crop belonging to the family Fabaceae, is always cultivated as a winter (Rabi) crop throughout India. Chickpea is a good source of protein (25.3$28.9 \%)$, fibre $(3.0 \%)$, oil (4.8-5.5\%), ash $(3.0 \%)$, calcium $(0.2 \%)$, phosphorus $(0.3 \%)$. In India the important chickpea producing states are Madhya Pradesh, Uttar Pradesh, Rajasthan, Maharashtra and Andhra Pradesh 
(Jodha and Subb Rao, 1987). In India, chickpea was grown on 9.01 million hectares area with total production of 7.58 million tones and an average productivity of $841 \mathrm{~kg}$ /ha (Anonymous, 2011). India is world's largest consumer as well as world's largest producer of chickpea and contributing over $70 \%$ of total global chickpea production (FAO, 2017). The world average chickpea yield is less than $1 \mathrm{t} / \mathrm{ha}$ which is far less than the potential yield of $6 \mathrm{t} / \mathrm{ha}$ under favorable and irrigated conditions (Varshney et al., 2017). This enormous disparity between the actual and expected yield of chickpea is due to biotic stresses, caused by insects, bacteria, fungi, nematodes and viruses, and abiotic stresses, such as drought, nutrient deficiencies, salinity and chilling (Roorkiwal et al., 2016). Plant-parasitic nematodes constrain chickpea production, with annual yield losses estimated to be $14 \%$ of total global production. Chickpea is a host for over 100 species of plant-parasitic nematodes (Nene et al., 1996; Sikora et al., 2018). Ali (1995) listed 97 nematode species associated with chickpea on global basis, out of which 64 have been reported from India, but the major damage is caused by three endoparasitic nematodes viz., Meloidogyne spp., Heterodera spp. and Rotylenchulus reniformis, which are known to inhabit inside the roots (Ali et al., 2003). Three species of the root-knot nematode, $M$. incognita, $M$. javanica and $M$. arenaria are associated with chickpea. Of these species, $M$. incognita is apparently the most predominant which is closely followed by M. javanica (Sharma and Sharma, 1998). Due to nematode infection plant shows various morphological responses like severe stunting, chlorosis, wilting and drooping of leaves, delay in flowering, fruit formation and yield, aggregation of nutrition deficiencies and retardation of growing point of shoot and root system with severe root galling due to hypertrophic and hyperplasia activities in the root tissues under the influence of endoparasitic sedentary nematodes. Plant-parasitic nematodes contribute to decreased plant vigor by reducing Rhizobium root nodulation and nitrogen-fixing ability of the host plant (Tiyagi and Parveen, 1992; Vovlas et al., 1998; Wood et al., 2018). Furthermore, plantparasitic nematodes exacerbate crop damage caused by other biotic stresses. Nematode infection leads to enhanced severity of infection with soil-borne fungal pathogens causing Fusarium wilt (Fusarium oxysporum f. sp. ciceris) (Castillo et al., 1998, 2003) and dry root rot (Rhizoctonia bataticola) (Ali and Sharma, 2003). Integration of resistant crops with appropriate agronomic practices is recognized as the long term safest and most practical, economic and effective control strategy for plant-parasitic nematodes. Resistance is the ability of a plant to reduce nematode reproduction such that, no nematode reproduction occurs in a highly resistant plant, a low level of reproduction occurs in a moderately resistant plant and unhindered nematode reproduction occurs in a susceptible plant (Roberts, 2002).Keeping in mind the above information available the present experiment was conducted to find the resistance in some chickpea germplasm against root knot nematode, $M$. incognita.

\section{Materials and Methods}

Pot experiments were conducted with 60 chickpea germplasm in the net house condition at the Directorate of Research, Bidhan Chandra Krishi Viswavidyalaya, Kalyani, Nadia, West Bengal, during December 2018 - February, 2019 to investigate response of the germplasms against root knot nematode, Meloidogyne incognita (Kofoid and White) Chitwood race 2 following completely randomized block design. The net house is located at $22^{\circ} 56^{\prime} \mathrm{N}$ latitude $88^{\circ} 32^{\prime} \mathrm{E}$ and at 9.75 meter above mean sea level. The germplasm lines were 
collected from the Project coordinating cell, AICRP on nematodes, ICAR New Delhi. To perform this experiment during the period of research, pure culture of $M$. incognita race- 2 was maintained on brinjal roots in the net house. Extraction of nematode eggs was done by using modified method (Hussey and Barker, 1973). Juveniles were also extracted from infested brinjal roots, using modified Baermann tray method. Counting was done three times to obtain the mean number of juveniles. Potting medium used was comprised of soil, sand and vermicompost in $3: 1: 1$ ratio. The required amount of media was sterilized by $10 \%$ formaldehyde solution to make the media free from nematodes. The potting media was ready to use after three weeks of sterilization. The earthen pots (6 ") were filled with sterilized soil @ 1000 cc pot. Sowing of chickpea seeds was done. Three seeds were sown in each pot and only one plant per pot was allowed to grow after one week of germination. The inoculation was done at 3-4 leaves stage (15 days after sowing) @ one J2 per cc of soil i.e. 1000 J2 per pot collected from the pur culture maintained in brinjal roots. For the inoculation three to four holes to a depth of 3 $5 \mathrm{~cm}$ were made with the help of glass rod near the rhizosphere. The second stage juveniles (J2) of Meloidogyne incognita@ $1000 \mathrm{~J} 2$ plant per pot were released with the help of $10 \mathrm{ml}$ pipette. Holes were subsequently covered with soil and pots were watered after inoculation. Four replications for each entry was maintained. The chickpea plants were uprooted after 45 days of inoculation carefully to avoid the damage of roots and other plant parts. The observations on shoot length, root length, fresh root weight, dry root weight, fresh shoot weight, dry shoot weight, root knot index (0-5 scale), egg masses per plant were taken. After uprooting the roots were gently washed in tap water and made cut at the junction of the shoot and root. Observation on length $(\mathrm{cm})$ of shoot and root, weight $(\mathrm{g})$ of shoot and root were recorded thereafter. Roots were brought to the laboratory for further studies. Counting of galls and egg masses were carried in the laboratory under stereozoom binocular. After counting roots as well as shoots were kept in paper packets for drying in dry air oven at $45^{\circ} \mathrm{C}$ for $4-5$ days and then dry weight was taken. The degree of resistance was indicated by the root knot index and it was done as per Heald et al., The critical difference (CD) at $5 \%$ level of significance was worked out from the data recorded during experiment and compared according to Duncan's Multiple Range Test at 5\% level of probability; the data was analyzed in CRD.

\section{Results and Discussion}

The experimental result revealed that the chickpea accession DBGV 218 was recorded for the greatest plant height, $95 \mathrm{~cm}$ and the lowest height, $24 \mathrm{~cm}$ was obtained in chickpea accession HK 16-30. It was also found that in reference to plant height 3 accessions were having no significant difference with DBGV 218 and 22 accessions had no significant difference with HK 16-30. Height of rest of the plants was significantly different from the tallest and the smallest ones. Chickpea accession IPCK 09-145 was recorded for the greatest fresh shoot weight, $18.05 \mathrm{~g}$ and the lowest weight, $0.86 \mathrm{~g}$ was

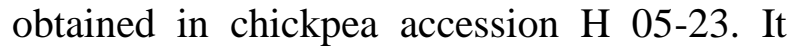
was also found that in reference to fresh shoot weight 1 accession was having no significant difference with IPCK 09-145 and 36 accessions had no significant difference with $\mathrm{H}$ 05-23. Fresh shoot weight of rest of the plants was significantly different from the heaviest and the lightest ones. It was observed that the chickpea accession IPCK 09-145 was recorded for the greatest dry shoot weight, $4.38 \mathrm{~g}$ and the lowest weight, $0.05 \mathrm{~g}$ was obtained in chickpea accession MABC-WRSA 1. It was also found that in reference to 
dry shoot weight 1 accession was at par with IPCK 09-145 while 37 accessions had no significant difference with MABC-WR-SA 1.
Dry shoot weight of rest of the plants was significantly different from the heaviest and the lightest ones.

Table.1 Evaluation of different chickpea germplasms against root knot nematode

\begin{tabular}{|c|c|c|c|c|c|c|c|c|}
\hline \multirow[t]{2}{*}{ Germplasm } & \multicolumn{3}{|c|}{ Shoot Parameters } & \multicolumn{3}{|c|}{ Root parameters } & \multirow{2}{*}{$\begin{array}{l}\text { Root } \\
\text { Knot } \\
\text { Index }\end{array}$} & \multirow[t]{2}{*}{ Reaction } \\
\hline & $\begin{array}{l}\text { Shoot } \\
\text { length }\end{array}$ & $\begin{array}{l}\text { Fresh } \\
\text { shoot } \\
\text { weight }\end{array}$ & $\begin{array}{l}\text { Dry } \\
\text { shoot } \\
\text { weight }\end{array}$ & $\begin{array}{l}\text { Root } \\
\text { length }\end{array}$ & $\begin{array}{l}\text { Fresh } \\
\text { root } \\
\text { weight }\end{array}$ & $\begin{array}{l}\text { Dry root } \\
\text { weight }\end{array}$ & & \\
\hline JG 2018 -54 & 48.667 & 4.01 & 1.11 & 9 & 0.25 & 0.11 & 2 & $\mathbf{R}$ \\
\hline Pant G 5 & 68.33 & 8.68 & 2.48 & 13 & 0.93 & 0.2 & 2 & $\mathbf{R}$ \\
\hline GJG 1603 & 56.33 & 3.5 & 0.93 & 8.33 & 1.26 & 0.5 & 2.33 & MR \\
\hline PhuleG 16111 & 59 & 5.51 & 1.63 & 9.33 & 1.8 & 0.38 & 4.66 & HS \\
\hline GL 17101 & 60 & 5.78 & 1.31 & 9 & 0.61 & 0.06 & 2 & $\mathbf{R}$ \\
\hline PG 186 & 53.67 & 4.26 & 0.85 & 8.33 & 0.51 & 0.03 & 2 & $\mathbf{R}$ \\
\hline NBeG 620 & 64.33 & 5.18 & 1.15 & 10 & 1.15 & 0.13 & 2.33 & MR \\
\hline H 15-13 & 70.33 & 8.4 & 2.15 & 10 & 0.9 & 0.16 & 2 & $\mathbf{R}$ \\
\hline PhuleG 1010-14 & 68.33 & 6.58 & 1.93 & 13.33 & 1.73 & 0.3 & 3.66 & $\mathbf{S}$ \\
\hline VIJAY & 62.67 & 4.81 & 1.16 & 9 & 1.2 & 0.18 & 3 & MR \\
\hline GL 29098 & 64.33 & 3.6 & 0.86 & 10.33 & 0.8 & 0.06 & 2 & $\mathbf{R}$ \\
\hline Phule G 15109 & 54.33 & 5.96 & 1.46 & 7 & 0.95 & 0.11 & 3.66 & $\mathbf{S}$ \\
\hline CSJ 881 & 62.33 & 11.78 & 2.1 & 10 & 1.53 & 0.23 & 3.66 & $\mathbf{S}$ \\
\hline GJG 1611 & 91.67 & 16.65 & 3.85 & 10.67 & 1.76 & 0.23 & 2.66 & MR \\
\hline BDNG 16-2 & 84 & 11.31 & 2.01 & 10.67 & 2.01 & 0.33 & 3.33 & $\mathbf{S}$ \\
\hline DBGV 218 & 95 & 11.68 & 2.83 & 9.33 & 1.06 & 0.11 & 2.33 & MR \\
\hline BDNG 21-1 & 55.67 & 9.63 & 1.46 & 9 & 0.5 & 0.06 & 3 & MR \\
\hline CSJ 515 & 60.67 & 4.66 & 0.96 & 10 & 0.55 & 0.06 & 2.33 & MR \\
\hline VIJAY & 61.67 & 8.26 & 1.7 & 11 & 1.2 & 0.15 & 2 & $\mathbf{R}$ \\
\hline NBeG 778 & 80.66 & 11.1 & 3.41 & 9 & 2.06 & 0.33 & 2.33 & MR \\
\hline H 15-18 & 76.33 & 7.75 & 1.46 & 9.66 & 0.76 & 0.06 & 2.33 & MR \\
\hline RLBGK 1 & 66 & 11.68 & 1.58 & 14 & 1.4 & 0.3 & 2 & $\mathbf{R}$ \\
\hline GLK 28127 & 68 & 6.31 & 1.73 & 12 & 1.33 & 0.1 & 2 & $\mathbf{R}$ \\
\hline Phule G 0517 & 65 & 3.35 & 1.1 & 11.33 & 1.25 & 0.2 & 3 & MR \\
\hline NBeG 810 & 77.33 & 10.16 & 2.58 & 13 & 1.58 & 0.16 & 2.33 & MR \\
\hline IPCK 09-145 & 85.33 & 18.05 & 4.38 & 10 & 1.76 & 0.23 & 2.66 & MR \\
\hline GLK 28127 & 26.67 & 2.55 & 0.1 & 30 & 1.56 & 0.04 & 4.66 & HS \\
\hline PF219 & 25 & 2.36 & 0.06 & 9.67 & 3.01 & 0.01 & 3.66 & $\mathbf{S}$ \\
\hline CSJK 142 & 28.33 & 1.26 & 0.18 & 26.33 & 2.26 & 0.11 & 5 & HS \\
\hline HK 16-30 & 24 & 2.55 & 0.28 & 19.33 & 0.86 & 0.26 & 3.66 & $\mathbf{S}$ \\
\hline HK 13-114 & 27.67 & 1.06 & 0.13 & 18 & 2.21 & 0.15 & 5 & HS \\
\hline Phule G 0517 & 37.33 & 3.1 & 0.5 & 21.67 & 5.18 & 0.38 & 5 & HS \\
\hline PG220 & 26.33 & 1 & 0.08 & 13.33 & 1.71 & 0.11 & 4.66 & HS \\
\hline BG 4009 & 30 & 1.16 & 0.11 & 18.67 & 2.15 & 0.11 & 5 & HS \\
\hline NBeG 723 & 30 & 1.2 & 0.15 & 19 & 1.41 & 0.26 & 4.66 & HS \\
\hline GLK 17316 & 36 & 1.38 & 0.1 & 17.33 & 3.91 & 0.67 & 4.66 & HS \\
\hline Phule G 8108 & 40.67 & 2.06 & 0.3 & 14.67 & 5.16 & 0.3 & 5 & HS \\
\hline
\end{tabular}




\begin{tabular}{|c|c|c|c|c|c|c|c|c|}
\hline JG 2016-24 & 42 & 3.85 & 0.6 & 23 & 5.41 & 0.23 & 5 & HS \\
\hline Phule G 16105 & 38.33 & 2.06 & 0.3 & 18.33 & 4.8 & 0.33 & 5 & HS \\
\hline PhuleG 1012-15 & 38 & 2.03 & 0.3 & 19.66 & 4.11 & 0.18 & 5 & HS \\
\hline RG 2015-01 & 40.33 & 4.81 & 0.58 & 15.66 & 6.55 & 0.21 & 5 & HS \\
\hline CSJ 995 & 35 & 2.01 & 0.31 & 15.66 & 4.21 & 0.66 & 5 & HS \\
\hline NBeG 779 & 48 & 2.7 & 0.26 & 19.33 & 6.11 & 0.21 & 5 & HS \\
\hline H $05-23$ & 26 & 0.86 & 0.08 & 14.33 & 2.56 & 0.18 & 4.66 & HS \\
\hline H15-04 & 29 & 1.67 & 0.2 & 14 & 2.86 & 0.21 & 5 & HS \\
\hline PG 217 & 32.33 & 2.05 & 0.13 & 16.33 & 4.4 & 0.28 & 5 & HS \\
\hline CSJ 515 & 34.67 & 2.78 & 0.13 & 21 & 4.83 & 0.31 & 5 & HS \\
\hline CSJ 996 & 39 & 2.08 & 0.31 & 16.33 & 4.3 & 0.28 & 5 & HS \\
\hline GL 16056 & 30.67 & 1.78 & 0.23 & 14 & 2.43 & 0.83 & 5 & HS \\
\hline PG 218 & 47.33 & 2.58 & 0.33 & 19.33 & 4.41 & 0.3 & 5 & HS \\
\hline BGM 10218 & 42.33 & 3.33 & 0.21 & 25.33 & 5.36 & 0.28 & 5 & HS \\
\hline BG 3097 & 39 & 3.43 & 0.46 & 23.67 & 5.73 & 0.31 & 5 & HS \\
\hline BGM 10216 & 29 & 1.76 & 0.28 & 16.67 & 3.23 & 0.16 & 5 & HS \\
\hline MABC-WR-SA 1 & 31.33 & 1.55 & 0.05 & 17.33 & 2.13 & 0.05 & 5 & HS \\
\hline MABC-WR-SA 2 & 32.67 & 0.86 & 0.16 & 15 & 0.78 & 0.23 & 4 & $\mathbf{S}$ \\
\hline МАВС-66-266 & 31.33 & 0.95 & 0.1 & 12.33 & 2.16 & 0.15 & 5 & HS \\
\hline WRC 41-111 & 28 & 1.03 & 0.11 & 13.33 & 2.1 & 0.1 & 5 & HS \\
\hline BGM 20211 & 33.33 & 1.93 & 0.08 & 22.67 & 3.43 & 0.23 & 5 & HS \\
\hline BGM20212 & 25 & 0.9 & 0.06 & 11 & 1.13 & 0.03 & 4.66 & HS \\
\hline ANNEGIN & 34.67 & 2.16 & 0.13 & 15.67 & 3.66 & 0.21 & 5 & HS \\
\hline $\operatorname{Lsd}(5 \%)$ & 12.59 & 3.50 & 0.98 & 6.69 & 1.75 & 0.27 & 0.18 & - \\
\hline CV & 16.10 & 46.73 & 65.21 & 28.40 & 44.21 & 80.42 & 4.85 & - \\
\hline
\end{tabular}

$\mathrm{R}=$ Resistant, $\mathrm{MR}=$ Moderately resistant, $\mathrm{S}=$ Susceptible and HS=Highly susceptible

Table.2 Correlation between root knot index and other parameters

\begin{tabular}{|l|l|l|l|l|l|l|}
\hline Parameters & $\begin{array}{l}\text { Root } \\
\text { length }\end{array}$ & $\begin{array}{l}\text { Shoot } \\
\text { length }\end{array}$ & $\begin{array}{l}\text { Fresh root } \\
\text { weight }\end{array}$ & $\begin{array}{l}\text { Fresh } \\
\text { shoot } \\
\text { weight }\end{array}$ & $\begin{array}{l}\text { Dry } \\
\text { root } \\
\text { weight }\end{array}$ & $\begin{array}{l}\text { Dry } \\
\text { shoot } \\
\text { weight }\end{array}$ \\
\hline Root Knot Index & -0.688 & -0.773 & 0.716 & -0.658 & 0.296 & -0.705 \\
\hline
\end{tabular}

With regard to root length, the chickpea accession, GLK 28127 exhibited longest root length, $30 \mathrm{~cm}$ whereas the smallest root length $7 \mathrm{~cm}$ was recorded with the accession Phule G 15109. It was also recorded that another 3 accessions and 29 accessions were statistically indifferent with the accessions GLK 28127 and Phule G 15109 respectively. Root length of rest 26 accessions was statistically different from both the longest and smallest root. With regard to root length, the chickpea accession, GLK 28127 exhibited longest root length, $30 \mathrm{~cm}$ whereas the smallest root length $7 \mathrm{~cm}$ was recorded with the accession Phule G 15109. It was also recorded that another 3 accessions and 29 accessions were statistically indifferent with the accessions GLK 28127 and Phule G 15109 respectively. Root length of rest 26 accessions was statistically different from both the longest and smallest root. Performance trend of germplasms with regard to dry root weight of the plants was same as was noted in case of the fresh root weight. The greatest dry root weight $0.83 \mathrm{~g}$, the smallest dry root weight $0.01 \mathrm{~g}$, were 
recorded for GLK 16056 and GLK 28127 respectively. 2 accessions were at par with GLK 16056 while 41 were statistically indifferent with the accession GLK 28127.In reference to root-knot index, 9 germplasms were recorded resistant, 12were moderately resistant and 7 germplasms were susceptible and 32 highly susceptible. However, interestingly nine germplasms exhibited no statistically significant difference with the smallest value of root-knot index (Table 1). The correlation of root knot index with both root and shoot attributes conforms that the growth of root length, shoot length, fresh shoot weight and dry shoot weight is negatively correlated to the root knot index ( $\mathrm{r}$ $=-0.688,-0.773,-0.658,-0.705$ respectively) while fresh root weight and dry root weight, were positively correlated with root knot index ( $\mathrm{r}=0.716,0.296$ respectively) (Table 2).

According to El-Sherif et al., (2007), rootknot nematode increases root weight for the most susceptible cultivar compared to resistant cultivar. This is because root-knot functions as metabolic sinks similar to a developing fruit as nutrients produced in the leaves are re-distributed rapidly to the roots and into the bodies of the nematodes.

\section{Acknowledgement}

The authors are deeply indebted to the Project Coordinator, AICRP on Nematodes in Agriculture, New Delhi for providing all the facilities to carry out the study. Director of Research, Bidhan Chandra Krishi Viswavidyalaya, Kalyani, Nadia is also highly acknowledged by the senior author for providing necessary infrastructural facilities to carry out the research work.

\section{References}

Ali SS, Sharma SB, Mishra SD. Nematodes of chickpea and their management. In:
Chickpea Research in India. A. Masood, S. Kumar and N.B. Singh (eds.), IIPR, Army Printing Press, Lucknow, India, 2003, 261-288.

Ali SS. Nematode problems in chickpea. Indian Institute of Pulses Research, Kanpur, India, 1995;

Ali, S. S., and Sharma, S. B. 2003. Nematode survey of chickpea production areas in Rajasthan, India. Nematol. Mediterr. 31, 147-149.

Anonymous, 2011. Agropedia, area, production and productivity of major pulses, Pulses Development Schemes. ZPD, Kanpur.

Castillo, P., Mora-Rodríguez, M. P., NavasCortés, J. A., and Jiménez-Díaz, R. M. 1998. Interactions between Pratylenchus thornei and Fusarium oxysporum $f$. sp. ciceris on chickpea. Phytopathology 88, 836-844. doi: 10.1094/PHYTO.1998. 88.8.828

Castillo, P., Navas-Cortés, J. A., Gomar Tinoco, D., Di Vito, M., and JiménezDíaz, R. M. 2003. Interactions between Meloidogyne artiella, the cereal and legume root-knot nematode, and Fusarium oxysporum $f$. sp. ciceris race 5 in chickpea. Phytopathology 93, 1513-1523. doi:

10.1094/PHYTO.2003.93.12.1513

Chand, L. and Srivastava, S.C. 1982. Pulse production in Madhya Pradesh. JNKWRes. J. 16: 86-94.

El-Sherif, A. G., Refaei, A. R., El-Nagar M. E., and Salem, H. M. M. 2007. The role of eggs inoculum level of Meloidogyne incognita on their reproduction and host reaction. African J. Agric. Res. 2: 159-163.

FAO, 2017. Production Crops [Online]. Rome: Food and Agriculture Organization of the United Nations.

Heald CM, Bruton BD, Davis RM. 1989. Influence of Glomus intradicesand soil phosphorus on $M$. incognita infecting 
Cucumis melo. Journal of nematology. 21(1):69-73.

Hussey RS, Barker KR. 1973.A comparison of methods of collecting inocula of Meloidogyne spp., including a new technique. Plant Disease Rept. 57:1025-1028.

Jeswani, L.M. and Vanchaik, PH. 1986. Coordinated Pulse Project, its Prospects, Ind Farming 17: 5-6.

Jodha, N.S. and SubbRao, K.V. 1987. Chickpea: World Importance and Distribution. In: The Chickpea (Saxena, M.C. and Singh, K.B., eds), CAB International, Oxford, pp. 1-10.

Nene, Y. L., Sheila, V. K., and Sharma, S. B. 1996. A World List of Chickpea and Pigeonpea Pathogens. Patancheru: International Crops research Institute for Semi-Arid Tropics.

Roberts, P. 2002. "Concepts and consequences of resistance," in Plant Resistance to Parasitic Nematodes, eds J. Starr, R. Cook, and J. Bridge (Wallingford: CABI Publishing), 2341. doi: 10.1079/9780851994666.0023

Roorkiwal, M., Rathore, A., Das, R. R., Singh, M. K., Jain, A., Srinivasan, S., et al., 2016. Genome-enabled prediction models for yield related traits in chickpea. Front. Plant Sci. 7:1666.

Sharma R, Sharma SB. 1988. Nematode pests of chickpea and their management in: Nematode Diseases in Plants. P. C.
Trivedi (eds.), CBS Publishing and Distributors, Daryaganj, New Delhi, 98-109.

Sikora, R. A., Claudius-Cole, B., and Sikora, E. J. 2018. "Nematode parasites of food legumes," in Plant Parasitic Nematodes in Subtropical and Tropical Agriculture, 3rd Edn, eds R. Sikora, D. Coyne, J. Hallmann, and P. Timper (Boston, MA: CABI), 290-345. doi: 10.1079/9781786391247.0290

Tiyagi, S. A., and Parveen, M. 1992. Pathogenic effect of root-lesion nematode Pratylenchus thornei on plant growth, water absorption capability, and chlorophyll content of chickpea. Int. Chickpea Newslett. 26, 18-20.

Varshney, R. K., Thudi, M., and Muehlbauer, F. J. 2017. "The chickpea genome: An introduction," in The Chickpea Genome, eds R. Varshney, M. Thudi, and F. Muehlbauer (Cham: Springer).

Vovlas, N., Castillo, P., and Troccoli, A. 1998. Histology of nodular tissue of three leguminous hosts infected by three root-knot nematode species. Int. J. Nematol. 8, 105-110.

Wood, C. W., Pilkington, B. L., Vaidya, P., Biel, C., and Stinchcombe, J. R. 2018. Genetic conflict with a parasitic nematode disrupts the legume-rhizobia mutualism. Evol. Lett. 2, 233-245. doi: $10.1002 /$ evl3.51.

\section{How to cite this article:}

Rayanta Kumar Lala, S. Mondal (Ghosh) and Chakraborty, G. 2020. Reaction of Some Chickpea Germplasm Lines against Root Knot Nematode, Meloidogyne incognita (Kofoid and White) Chitwood. Int.J.Curr.Microbiol.App.Sci. 9(10): 1773-1779. doi: https://doi.org/10.20546/ijcmas.2020.910.215 